\title{
THE RHETORICAL EVOLUTION OF THE MINIMUM WAGE
}

\section{By}

Oren M. Levin-Waldman*

Working Paper No.280

September 1999

*Resident Scholar, The Jerome Levy Economics Institute 


\begin{abstract}
The concept of the minimum wage has undergone several rhetorical permutations. Originally conceived as a living wage, which would function as a family wage, it ultimately became a matter of macroeconomic policy, the goals of which were to achieve greater efficiency and in some cases economic development. In recent years, the rhetoric has narrowed to a debate that pits a youth disemployment effect against assisting the poor. This paper traces the rhetorical evolution of the minimum wage and shows how the rhetoric employed by various groups has been shaped by the specifics of the political and economic environment.
\end{abstract}


E.E. Schattshneider (1960) once observed that politics essentially boils down to efforts by two groups to either socialize or localize conflict. Those seeking to contain a conflict will define an issue narrowly and those seeking to socialize will define it broadly. Politics becomes a matter of how bias is mobilized to affect the outcome.

The evolution of the minimum wage in the United States can be viewed very much within this context. How it is conceived determines the degree to which it obtains political support. Opponents of the minimum wage have successfully localized the conflict by making two arguments. First, most minimum wage workers are either teenagers or secondary earners (Burkhauser and Finegan 1989), and therefore a minimum wage intended to assist the poor would be poorly targeted at alleviating poverty. Second, minimum wage increases lead to lower employment among the primary segment of the labor market that earns the minimum wage: teenagers (Kosters and Welch 1972, Meyer and Wise 1983, Neumark and Wascher 1992, Kosters 1996). By positing the argument narrowly in terms of a youth disemployment effect, opponents successfully make the political case that the minimum wage is not an issue that most of us should care about. By treating supporters as only concerned with matters of poverty, they have successfully defined the parameters of debate as a standoff between those arguing the youth disemployment effect on the one hand and those arguing the poverty benefits on the other. Viewing the wage strictly in this manner ignores broader distributional and institutional implications (Baldwin and Goldfarb 1996), such as the effects that the minimum wage might have a community's wage structure and its distribution of income (Galbraith 1998, Palley 1998, Levin-Waldman 1999a).

For supporters, however, the issue has always been much larger. Over the last century proponents of the minimum wage have couched their arguments in terms of macroeconomic questions: how best to achieve greater efficiency and create a more just society (Webb 1912; Prasch 1998; Levin-Waldman forthcoming). Though conceptions of justice vary, for the purposes of this paper I will define a just society in substantive terms as a society whereby workers earn wages sufficient to sustain themselves and their families. A just society is one where people who work should be entitled to an income that enables them to live in dignity and out of poverty because it is a matter of fairness. Minimum wage supporters have generally attempted to socialize the conflict by placing the debate in terms of a societal issue (i.e an issue of concern to all because it affects us all) rather than as only a poverty issue (i.e a narrow issue of concern to only a small sub-population). Moreover, Congress has been more likely to pass minimum wage increases when there has been a clear base of political support, and this base has 
tended to be organized labor (Levin-Waldman 1998a).

The concept of the minimum wage has undergone several rhetorical permutations. During the late nineteenth century, it was initially conceived as a living wage, which generally meant a wage sufficient to maintain a basic level of subsistence. Later it was seen as a family wage, as that which would promote a family because it would support the family. Then during the early part of the twentieth century, it became a minimum subsistence wage for women. With passage of the Fair Labor Standards Act (FLSA) in 1938, the minimum wage became an official weapon in the policy arsenal designed to not only assist the working poor but to prop up wages generally. In some parts of the country, particularly the South, it was viewed as a larger effort to achieve economic development (Schulman 1991).

In recent years, however, broader visions of the minimum wage, that is, those that would use the minimum wage to achieve larger macroeconomic goals such as wage stabilization or higher incomes that would increase purchasing power among consumers, appear to have gotten lost. Specifically, the perception that the War on Poverty and Great Society programs of the 1960s failed led some to conclude that the minimum wage too, by virtue of association, would also be an unsuccessful tool for assisting the poor. Because advocates of minimum wage increases often argue the benefits of increases to the poor, the concept continues to suffer from association with poverty policy in the United States.

It is ironic, then, that those arguing for a broader view of the minimum wage are expressing it in the earlier language of a "living wage." Various municipalities have passed living wage ordinances mandating that companies doing business with them pay their employees a living wage. Though there are differences to be sure, the rhetoric is all too familiar: People who work for a living are entitled to a wage that enables them to live above the poverty line with a measure of dignity. Supporters of recent minimum wage increases would, no doubt, argue that their support of the hikes was motivated by these ideals.

In this paper, I argue that rhetoric does matter. Rhetoric is the language that both expresses ideology and masks it. It is also the language through which political movements express themselves. Specifically, rhetoric is a product of the political environment, and rhetoric may have implications for political and social outcomes. 


\section{FROM LIVING WAGE TO MINIMUM WAGE}

Several municipalities, including Baltimore, Los Angeles, and Detroit have passed living wage bills and others, like Kalamazoo, are in the process of adopting them (Pollin and Luce 1998). The ordinances differ from statutory minimum wages in that municipal living wages require only those companies doing business with them to pay the specified wage. The Los Angeles City Council, for instance, recently voted to force the Department of Water and Power to adopt its living wage ordinance that requires contractors to pay $\$ 7.15$ an hour (Shuster 1998). The living wage movement in Los Angeles has begun efforts to target the L.A. county government to adopt the city's ordinance. Detroit's new living wage ordinance, approved by voters in a referendum, requires all contractors doing more than $\$ 50,000$ in business with the city to pay at least $\$ 7.70$ an hour plus health benefits. If benefits aren't included, they are required to pay a minimum of $\$ 9.63$ an hour (Hurt 1998). That such ordinances have been passed reflects the assumption that the current federal minimum wage of $\$ 5.15$ is inadequate to alleviate poverty and that the debate over the minimum wage in recent years has perhaps been too narrow. When President Clinton ran for office in 1992, he campaigned on a platform that everyone who works and plays by the rules is entitled to live above the poverty line. Those who argue for a "living wage" would no doubt argue that such a wage is key to independence. By earning such a wage, workers will not be dependent on the state. Moreover, given the message of recent welfare reform that greater independence (defined as non reliance on the state) is expected of individuals, living wages would appear to be critical to that realization.

Such arguments echo the living wage debates during the latter part of the $19^{\text {th }}$ century, to the extent that it was believed that workers should earn enough to support themselves and their families. Both the political and economic environment, however, were different then.

\section{.HISTORICAL DEVELOPMENT OF THE MINIMUM WAGE The Minimum Wage as a Living Wage}

The republican tradition stressed the independence of individuals as the basis for citizenship (Wood 1991; Foner 1998). One could only be independent to the extent that one could control one's own labor. Those who were forced to work for others, to in fact work for wages lost control of their labor and hence themselves. By this notion, then, wage labor was just another version of slavery. The living wage that was talked about during the latter part of the $19^{\text {th }}$ century, then, represented an attempt by wage laborers to not only be independent, but to cast aside the perception of their work as slave labor. 
The image of wage labor as slave labor is often associated with Marx's critique of capitalism found in his tract on labor processes in Capital (Marx 1967, vol.1, part 3). But the roots of this position in the U.S. stem from the republican tradition from which many American political institutions were founded (Wood 1972, Elkin 1987). Within this republican frame of mind, slavery and independence were not compatible. The concept of citizenship was literally grounded in a system of property ownership. Property owners were both independent and free citizens of the republic; slaves were not. But the economic foundations of the early republic that allowed individuals to be independent were changing. The great economic transformations that Polanyi wrote about were forcing more and more people into wage labor (Polanyi 1957). At issue for organized labor was how to make wage labor respectable. Also at issue was how to ground the essence of citizenship within a system of wage labor, where property ownership was not in land but in the labor power workers could sell.

Lawrence Glickman (1997) argues that most workers, especially organized workers, who sold their labor on the market - that is, men who earned wages-lost ownership of themselves to someone else who then had a great amount of power over them. The economic changes that were taking place transformed the role of the male worker into one analogous to women's role in the home. Men became dependent on the bosses in the same way that women were dependent on men in the family. Men forced to work for wages were no longer able to see themselves as independent citizens, but in effect became answerable to their bosses in much the same way that women were answerable to their husbands and fathers. Men who worked for such a low level of wages saw themselves as no different from prostitutes. The concept of a living wage, however, would enable them to rise above the shameful image of a prostitute. Social reformers and labor leaders who advocated living wages during the late part of the $19^{\text {th }}$ century viewed the living wage as one that would enable workers to achieve full citizenship. The focus shifted away from whether one worked for wages to the level of the wage, with a distinction made between living wages and subsistence wages.

Though the living wage was never precisely defined in dollar terms, it was thought that it should be high enough to enable a man to support a family. The family wage therefore was not the same as a statutory minimum wage, which was conceived of as a subsistence wage to be applied only to women.

For men, it was believed that living wages could be achieved by joining labor unions. Women, however, weren't allowed to join unions and so minimum wages applicable only to them would 
similarly free them from the same type of shame that men felt by virtue of having to work for wages in the first place.

The notion that a living wage would preserve the moral dignity of families was not merely a rhetorical device. For women in particular, the concept of a minimum wage would literally save them from a life of prostitution. Therefore, a common argument for why statutory minimum wages should be received by women was because they would better enable them to safeguard their morals. Among the $20^{\text {th }}$ century reformers, Emile Hutchinson (1919) made the point that women's wages, which had long been low relative to men's, were of particular concern because of the relationship to morality issues. "It decides the girl's companionships, her amusements, her ability to gratify without danger her natural and reasonable tastes, her very capacity for resistance to temptation. Its physical effects open the way to moral dangers (p. 50)." Women who could not earn subsistence wages might find themselves pulled in the direction of prostitution, which at the time was not illegal. In a similar vein, social reformers argued for mothers' pensions - the forerunner to the Aid to Families with Dependent Children's program - because these pensions would enable them to safeguard their morals while also caring for their children, which in the reformers' view was best done in the home (Mink 1995). At the same time, these same social reformers weren't feminists in today's sense. The language often used during this period in support of minimum wages for women was that of a "women's" wage, but relative to a living wage earned by men. Alice Kessler-Harris sums it up this way: That men ought to be able to support wives and daughters implied that women need not engage in such support. They ought to be performing home duties. Thus if women earned wages, the normal expectation was that she did so to supplement those of other family wage earners (Kessler-Harris 1988, p. 8).

As much as reformers wanted to achieve more equitable pay for women, they also believed the ideal — though it would not necessarily apply to them — would be for women to be paid equally to men, but with the goal of effectively excluding women from the labor market so that they would stay home with their children (Kirkby 1987).

Despite these varied terms, at root was a desire to achieve a minimum wage. To a large extent, there was little difference between a living wage, which was also a family wage, and a minimum wage for women, despite the fact that the concept may have conjured up different images for different people. Yet, the different terms were not merely plays on words. The use of language in part reflected the political realities of the time.

During the early years, at precisely the time that these different terms were being employed by different movements, there also were constitutional limits placed on the imposition of wage 
controls for men that did not exist for women. Men enjoyed liberty of contract - the ability as free and equal citizens to negotiate with their employers the terms under which they would work for a living. Women, however, did not enjoy the same liberty of contract because the courts did not view women's citizenship in quite the same way as it did for men. The 1908 case of Mueller v. Oregon established that women, because of their maternal function-understood to be of greater social value than the mere protection of private property rights-did enjoy a protected status (28 Supreme Court Reporter 1907). By 1923, however, this view changed when the Court in Adkins v. Children's Hospital upheld that a minimum wage in the District of Columbia did now violate a women's liberty of contract. Did women suddenly have less of a maternal function? The court in Adkins viewed women as equal citizens because, through constitutional amendment only three years before, they acquired the right to vote. As a result, women enjoyed the same liberty of contract as men (261 U.S. 1922). Because the minimum wage was viewed as the only type of wage regulation attainable for women, those who advocated a minimum wage for women also saw it as a vehicle for attaining a living wage.

Susan Lehrer makes the argument that social reformers during the Progressive era did not challenge the practice of a gender segregated labor market or its underpinning assumption that a women's primary place was in the home (Lehrer 1987). But protective labor legislation played an important role in the process of defining the position of working women in industrial capitalism. Social reformers viewed protective labor legislation as one means of limiting the initial exploitation and orientation of women workers. At the same time, these laws were seen as contributing to labor productivity by forcing employers to use labor more "effectively." That is, employers forced to pay women a higher wage would opt to hire their husbands because of the belief that they were more productive, and women would then be able to remain at home. Still, there were many women in the labor force at the time who were not married, and for them such reforms were seen as a necessary ingredient to providing them with subsistence and guarding their morals.

The American Federation of Labor (AFL) was initially opposed to statutory minimum wages because they wanted men to join labor unions, but later came to support them for women. The union's principal goal was to raise men's wages to a level adequate to support a family (Lehrer 1987). The AFL believed that hiring women would effectively impoverish whole families. Women were thus urged to adopt strategies that would enable them to remain at home as wives and mothers. Therefore, it was often argued that the cost of women's low wages was not borne by women, but by society as a whole. As Hart suggests, many of those who argued for a minimum wage "often did so with a heartfelt preference for the idealized family wage and 
gendered welfare state (Hart 1994, p. 16)." From the standpoint of the labor movement, a minimum wage restricted to women would in no way undermine men's ability to bargain for an even higher wage, particularly since women were not able to join labor unions.

\section{THE MINIMUM WAGE AS MACRO POLICY}

Willis Nordlund (1997) has argued that the history of the minimum wage in the United States could essentially be viewed as a quest for a living wage. Although this may largely be true, the economic environment of the time would indeed affect how the minimum wage was conceived as well as the rhetoric employed to sell it.

During the Great Depression of the 1930s, the minimum wage wasn't simply viewed as a measure for obtaining subsistence, but as a larger macroeconomic policy aimed at achieving stability. At a time when wages were depressed, both wage floors and policies encouraging unionism would serve to prop up wages and provide workers with purchasing power. And as Glickman (1997) argues, the earlier living wage movements were predicated on developing a consumer base, but during this time began to be viewed in a larger context.

In the South wages were considerably lower than in the North, and the minimum wage was viewed as a vehicle for achieving economic development (Schulman 1991). The South's limited industrial capacity was concentrated in low-wage, low productivity industries, such as textiles, hosiery, and lumber. New Deal planners, including President Roosevelt, believed that jobs in only the advanced manufacturing sector would pay high wages and provide the purchasing power and tax base necessary to stimulate the economy in the south. The Roosevelt administration also believed that high wages would increase the efficiency of southern workers. A minimum wage, first through the industry codes of the National Recovery Act (NRA) and then the Fair Labor Standards Act (FLSA), not only would raise wages of unskilled workers rise, thereby offering them greater purchasing power and a better standard of living, but employers would also be encouraged to modernize. The minimum wage would effectively make the South more efficient (Schulman 1991).

The notion that the minimum wage would lead to greater efficiency was nothing new. Economic theory had long maintained that minimum wages either lead to lower employmentbecause employers will be forced to lay off their least-skilled worker-or greater efficiencybecause employers will seek to increase output per worker to maintain profit rates (Stigler 1946). Earlier in the century, Sidney Webb (1912) argued that a legal minimum wage would 
have the positive effect of increasing productivity. A wage floor would be beneficial to employees and employers alike, because better paid people would be able to work harder because they have greater energy, due in large measure to their ability to better sustain themselves. Moreover, the greater morale among employees deriving from higher wage rates would lead to greater loyalty to their employers. As a result, productivity would naturally increase. A legal minimum wage, then, would positively increase the productivity of the nation's industry by ensuring that those who are left unemployed would be the least productive members of the workforce. Not only would employers be forced to look for the best workers so as to increase their overall productivity, employees would be forced to develop workers skills so that they could be counted among the better class of workers. Moreover, progressive reformers who sought to obtain minimum wage legislation for women often appealed to these types of efficiency arguments (Levin-Waldman 1998b). It appeared that New Deal reformers were appealing to the same arguments.

Others during the 1930s saw the use of the minimum wage and the language of southern economic development as an attempt to protect high-wage industries in the north from competition from the southern labor market. Gavin Wright (1986) has presented the southern labor market as a unique entity totally isolated from the national economy. Despite the fact that industry was moving into the South, production techniques rested by-and-large on low-skilled workers. Even though there were outside demands in terms of regional competitive pressures that other regions faced, which, according to economic theory, should have forced up wages in the South, most southern employers weren't paying wages any higher during the bustling 1920s than they had been prior to the economic boom of the 1920s. The national wage standards introduced during the 1930s, were, in effect, imposed on many southern industries, with textiles hit particularly hard.

The idea behind laws like the NRA and, later, the FLSA was that recovery could be encouraged by prohibiting firms from engaging in cutthroat competition. And indeed, the effects of these laws were far greater on low-wage industries than high-wage industries, and were experienced more in the South than in the North. Even a progressive like Walter Lippman referred to the FLSA as "in truth a sectional bill disguised as humanitarian reform (Lippman quoted in Wright 1986, pp. 222-223)." Or as Wright explains, the history of the southern economy is not a study of economic development, but a "case of a region being forced off of one growth trajectory and onto another, a case in fact of one large group of people being forced out of the economy altogether, and... another, more affluent group coaxed in (Wright 1986, p.237; cf Seltzer 1995)." 
Nevertheless, in response to claims that federal policy might drive certain firms out of business, the Roosevelt administration echoed an argument made by Edward Filene (1923) during the Progressive period that it might be better if these firms did go under. Filene argued that any business that could not pay a living wage - a wage sufficient to sustain a base of consumers who would be in a position to patronize other businesses-wasn't good for the community and had no right to be part of it.

The concept of a minimum wage as a vehicle to achieving a larger public purpose, whether it was the alleviation of poverty, economic development, or increased productivity often assumed the type of rhetoric that would promote that public purpose. Though the establishment of a minimum wage would no doubt alleviate the poverty of some in the short-term, poverty discourse, by and large, was not the prevailing rhetoric used to promote the minimum wage. More successful arguments in favor of the minimum wage generally employed other language.

What changed to narrow the scope of debate from these broad macroeconomic and efficiency arguments to the current debate between those who oppose minimum wage increases because it will result in primarily a youth disemployment effect and those who support it because it will assist the poor? It may be conceded that those who couch the issue within the narrow parameters of youth disemployment effects see themselves as being infused with a public purpose, namely maintaining employment opportunities for low-skilled workers and preventing inflation. An argument could be made that at the same time as the coalescence of certain political and economic circumstances (i.e. the process of industrialization and the resultant wage instability along with the need of politicians, especially the Democratic party, to build a broad electoral coalition that would include labor) served to broaden the scope of debate, the coalescence of other circumstances served to limit it. Among those other circumstances was the rise of what some might refer to as the new economism - the emergence of greater empiricism with an over reliance on statistical studies to demonstrate the effects of the wage on specific segments of the population (Nordlund 1997). When reformers were arguing for a minimum wage for women during the Progressive period, they relied on the burgeoning field of statistics to demonstrate the necessity of the wage for them. The new statistics, as they were often called, showed the extent to which female workers lived in poverty and how much they would need to subsist. During the 1950s, statistics began to be put to a new use: estimating the effects of minimum wage increases on both general employment levels and specific segments of the labor market. As part of the 1955 minimum wage amendments, a new evaluation program was mandated that would institutionalize routine statistical analyses of the wage, as well as estimates of its effects. More importantly, it would set the stage for a new drama that was to begin during 
the 1970s, namely studies that showed that minimum wage increases adversely affected teenagers. Not only were teenagers shouldering the brunt of these adverse effects, it was estimated that a 10 percent increase in the minimum wage would result in a teen disemployment effect of 1 to 3 percent (Brown, Gilroy, and Kohen 1982; Brown 1988). These studies came to form the basis of a consensus that was canonized as the standard conventional wisdom.

\section{THE END OF MACRO POLICY}

During the 1980s the nature of the political debate over the minimum wage began to change. The election of Ronald Reagan to the presidency marked the return to favor of the economic view that government was the problem, rather than the solution to the nation's economic and social problems. Summing up the goals of economic policy, George Stigler argued that "The supreme goal of the Western World is the development of the individual: The creation for the individual of a maximum area of personal freedom, and with this a corresponding area of personal responsibility (Stigler 1986, p. 93)." As noble as policies such as the minimum wage might be at providing a safety net or reducing income inequalities, they were fundamentally at odds with the tenets of personal freedom.

The Reagan administration made no secret of its views that too much interference in the economy was a reason the economy had been in a recession during the 1970s. Inflation was, in part, a product of wages being bid up, without corresponding gains to productivity, a problem attributed in large part to labor unions. Although the number of workers associated with unions never exceeded 30 percent of the total workforce during the 1950s, it dipped below 19 percent during the 1980s (Goldfield 1987). There are perhaps several reasons for why union membership has declined, but the Reagan administration's handling of the PATCO air traffic controllers strike stands out as important.

When PATCO went on strike, which for Federal workers was against the law, the response was both swift and harsh. President Reagan fired all striking workers, and in so doing sent a clear message to labor unions across the country, that any form of union militancy would not be tolerated (Dubofsky 1994). Although the NLRA never really barred the replacement of striking workers, until that point no employer had resorted to it for fear of the negative publicity that doing so might bring. But with Reagan's firing of PATCO workers, the earlier taboo had finally been broken (cf. Reich 1997). The result, as Michael Piore observes, was that it "galvanized anti-union managerial factions in a whole variety of industries and occupations where union organization had previously been unassailable. And it set the stage for a prolonged period of 
union give backs and concession bargaining."(Piore 1995) The firing of striking workers, was sent the signal as to how government viewed labor. Because labor was perceived as always demanding more money, it also came to be seen as the source of whatever economic problems were plaguing the country (Moody 1988, Palley 1998). In 1981 the minimum wage was raised and was not again raised until 1989. The minimum wage was essentially allowed to fall relative to average wages, from 47 percent in 1981 to 35 percent 1989, the longest and most sustained decline since the introduction of the minimum wage in the 1930s (Piore 1995, pp. 10, 14).

It was not just a question of whether there was a systematic strategy designed to maintain what Sabel and Piore (1984) call the "low-road"-low-wage strategies over high-wage strategies-but the shift of emphasis of government policy from one geared to the maintenance of full employment to one predicated on resisting inflation (Galbraith 1998, p. 10). To the extent that inflation became the chief priority, policies that could in any way boost wages were viewed as suspect. Also, given studies showing that minimum wages to benefit the poor were poorly targeted, the minimum wage was thought to be no longer any help in reducing poverty.

Consistent with these changing priorities, NLRB and Supreme Court decisions increasingly became hostile to union goals. The tendency was toward a more restrictive interpretation of the National Labor Relations Act (NLRA). There were several assumptions underlying a substantial portion of existing legal doctrine: 1) The continuity of production must be maintained and limited only when statutory language clearly protected employee interference; 2) Employees act irresponsibly unless controlled; 3) Employees possess limited status in the work place and, therefore, they owe a considerable measure of respect and deference to their employers; and 4) The enterprise is under management's control, with great stress being placed upon the employer's property rights in controlling the workplace. The NLRA was interpreted to mean that although the act might suggest participatory goals for workers, workers can never become full-fledged partners in any business, as such a partnership might interfere with management's exclusive property rights (Alterson 1989-90). This point became patently clear in First National Maintenance Corporation v. National Labor Relations Board when the Supreme Court ruled that management decisions to close a plant did not fall within the range of issues that would have to be discussed in collective-bargaining negotiations (452 U.S. 1980).

For some, the assault on unions and the decline in the value of the minimum wage was a matter of deliberate government policy aimed at achieving a low-wage economy (Moody 1988, Piore 1995, Prasch 1996, Galbraith 1998, Palley 1998). Not only was there an assault on labor, but the thrust of the new ideology was on dismantling the entire welfare state. In the area of social 
policy, the administration moved to limit eligibility for public assistance and reduce benefit levels. While assistance programs were being reduced, job training programs, like the Comprehensive Training Employment Program (CETA), were being completely eliminated. On the regulatory front, the administration was only accelerating the pace of deregulation begun in the Carter administration. Students of welfare policy were quick to label administration policy as a war on the poor with the intended goal being the creation of a reserve army of labor. At the very least, it appeared as though the interests of capital and the propertied classes were receiving a new Bill of Rights at the expense of workers and the poor (Piven and Cloward 1982; Bowles, Gordon and Weisskopf 1983; Dolbeare 1986; Fraser and Gerstle 1989; Katz 1989). It was also during this time that the number of minimum wage workers declined, the rate of poverty increased, and the value of the minimum wage dropped considerably.

On one level the decline of unions and the stagnation of the minimum wage really cannot be separated. On another level, the minimum wage policies were very much in keeping with the general climate of cuts to government programs. This shift in government policy reflected the new conservatism, which in many respects represented a return to classical liberalism's philosophy about the relationship between the individual and the state — an understanding also consistent with the re-emerging emphasis of free market ideology. The minimum wage as macro policy in part had rested on an assumption that low wages and general welfare were societal problems that the community at large had a responsibility to address. This was precisely the focus that Stigler argued against. Returning to a free market focus, the emphasis was on the individual to improve him/herself through education and training so that s/he would be in a position to command higher wages. It was not society's responsibility to raise wages.

To some extent, the political tide of the 1980s represented a return to the constitutional logic of the Lochner era- a period in American constitutional jurisprudential history that epitomized laissez-faire economics and the liberty of contract. During the Lochner era, the courts required convincing proof that a state action would not violate the rights of the individual, or, if it was to, it had to be clear that the public interest would be served (Tribe 1988, pp. 568-569). The focus on empiricism during the 1980s seemed to suggest the same, but with a different twist. That is, in the absence of any real proof that 1) the minimum wage did not cause unemployment and 2) a larger proportion of the labor market could benefit from a rise in the minimum other than teenagers, there was no legitimate basis to consider such an increase. In fact, the minimum wage study commission, also a defining characteristic of minimum wage legislation during the 1980s, appeared to confirm such thinking when it released findings that a 10 percent increase in the wage would result in a 1 percent decrease in employment among teenagers (Nordlund 1997, 
pp. 168-169).

The rhetoric also changed. For those who wanted to narrow the scope of debate, the focus was increasingly on the individual and the individual's need to obtain the requisite education and skills to justify higher wages. Just as much of the literature on poverty and welfare was moving away from structural concerns and focusing more on behavioral traits, so too the focus was shifting in the rhetoric about the minimum wage. The minimum wage, it was argued, need not be raised because individuals lacked the appropriate skills to justify higher pay. In this way, the minimum wage debate began to mirror the one on welfare, which conservatives argued created disincentives to work and relieved the poor of their personal responsibility (Murray 1984, Mead 1986). Just as the government did not owe the poor public assistance as compensation for their behavioral deficiencies, it did not owe them a guarantee of a living wage as compensation for their skills deficiencies. Testifying before a congressional committee Labor Secretary William Brock made it clear that the Reagan administration's position was that raising the minimum wage was bad policy because it would hurt younger workers and would not reduce poverty. The issue was not to help the working poor (or what some would regard as low-productivity workers) by raising the minimum wage; rather such workers would best be helped through education and training programs. As Brock put it:

Given the current job creation atmosphere and the increasing demand for a highly skilled and highly literate labor pool, we are indeed facing a crisis in this country. That crisis is the prospect of entering the next century with a bifurcated society - not simply divided between those who are employed unemployed, but more importantly, divided between those who are unemployable (U.S. Senate 1987, p. 15).

The rhetoric during the Bush administration was no different. Though willing to back a compromise plan on the minimum wage that included a subminimum or "training wage" for teenagers, the real issues were still considered to be education and training. If people wanted to earn more, it was incumbent upon them to acquire the training and skills necessary to command higher wages. Testifying before Congress, Labor Secretary Elizabeth Hanford Dole made it clear that improvements in training and education were the more urgent challenges to employment policy, especially since the real problem was a skills gap. As she stated: We need to recognize that the poverty population and the minimum wage earners are different people, by and large. We need to be clear about what we are trying to do. If we want to help people out of poverty, then we need to look at literary and basic skills, which are the root to the better-paying jobs our economy is creating. Raising the minimum wage has little relation either to skills provision or to the poverty population (U.S. Senate 1989, p. 20). 
Paul Kamolnick (1993) suggests that the politics of the minimum wage has always been at root another episode in the larger political class struggle over capitalist wage relations. The nature of these politics and the character of the debate suggest that for the future that minimum wage campaigns need to return to demands for a living wage as it was conceived by those who originally framed the FLSA in 1938. That is, because minimum wage debates at root represent manifestations of traditional class struggles, it would be useful to couch the debate in terms of what society owes to those workers, especially low-skilled ones, in terms of guaranteeing that they will be able to support themselves through work. Nonetheless such a focus could neglect another point. The use of rhetoric, especially the rhetoric of individualism, can effectively obscure the true intentions of any group that has a vested interest in a particular outcome. Over 50 years ago, George Orwell wrote about how euphemisms might easily be substituted for the purpose of masking what otherwise might be unpleasant (Orwell 1980). When managers talk about the inefficiency of the minimum wage, are they not really attempting to avoid the issue of whether in the absence of a wage floor there will be exploitation? Instead of explaining why workers in certain segments of the economy would earn lower wages in the absence of a minimum wage, one side of the debate distinguishes between low-productivity and highproductivity jobs. To state that low-productivity jobs aren't worth paying a higher wage for might be unpleasant. It might be even more unpleasant for mangers to state that they want to pay as little as possible, which could be interpreted as being exploitive. It is easier to couch the argument in terms of individualism and efficiency- "that we would like to pay more because workers should earn higher wages, but their productivity levels simply do not justify it."

Moreover, the individualistic rhetoric diverts attention from the system and lodges responsibility at the level of the individual. According to this individualistic rhetoric, the issue ceases to be one of whether employers should pay liveable wages or even be responsible for increasing their employees skill levels, and becomes one of whether the employee possesses sufficient skills to make him/her productive enough to command higher wages. If the issue is productivity the burden of raising it is placed on the individual and not the employer. Insofar as society may in any way be involved, the issue becomes whether government can offer the right types of programs aimed at raising the skill levels and, hence, the productivity, of workers. Politically speaking, employers bear no responsibility, which is in keeping with individualistic presuppositions underpinning America's political and economic culture.

By relying on this individualistic rhetoric, more communitarian notions of responsibility are effectively obscured. Ultimately, it is a question of maintaining communal welfare according to 
the shared values of the community. If we as a society maintain that work is ultimately what defines us as good citizens (Mead 1986, Kaus 1992, Glickman 1997), we ought to also take the view that one who is willing to work should be entitled to receive a liveable wage. People should have a right to live in dignity, which might entail receiving a living wage. They should be paid liveable wages so that communal arrangements will in fact be more equitable. The rhetoric of individualism, however, has shifted the focus away from a more communitarian focus and has ultimately led to a negation of communal responsibility for wage rates.

By placing the burden of skill acquisition on the individual, society doesn't have to confront the issue at all, let alone decide the appropriate policies that would yield higher wage rates. And yet, in certain types of jobs, such as in the fast food industry, or retail sales do not require skill worker upgrading. The question arises whether all employers are serious when they talk about improving their workers' skills, or if they simply are throwing up a canard as a way of diverting attention from what many of them may see as the crux of the matter? Though it cannot be proved, one can only speculate that at least some employers don't want to be forced to pay higher wages because there is a limit to how much at their cost increases they can pass onto consumers in the form of higher prices. By invoking the argument of the minimum wage workers' deficient skills, the onus is placed back on the workers. It is no longer a matter of employers exploiting workers by paying inadequate wages because these workers don't justify high wages. If there is no exploitation there can be no justification for the state interfering with otherwise normal exchange relationships.

In a real sense, by shifting the focus of the debate to the characteristics of individuals — particularly on any supposed deficiencies — rather than the various impersonal forces that resulted in the inequitable distribution of education and skills, results in absolving government of responsibility for initializing change. In a larger sense, the debate has come full circle to the point it was prior to the adoption of the minimum wage. In the early years, skill deficiencies were clearly there, but the liberty of contract argument was much stronger. During the 1930s, however, the liberty of contract argument had been discredited and all that was left was the skills deficiency. The early philosophical arguments about government's role in society had given way to the more analytical — and to some extent more practical—arguments of whether the benefits from the role government assumed justified the costs. What was perhaps lost in these analyses were the larger philosophical questions of what type of society we would like to create and whether or not there aren't some minimum standards for how people in our society should live. 
It is also important to note that this shift in focus in the 1980s was occurring amidst the growing criticism of the War on Poverty and Great Society programs of the previous decades. Although the issues debated about the War on Poverty and Great Society programs were different from those about the minimum wage, the confluence between them in public discourse led to negative attitudes about the minimum wage. Because the Great Society programs were perceived to be a failure, any program that could in any way be viewed as a measure for alleviating poverty was also thought, by definition, to be a failure. Moreover, the further identification of the War on Poverty with urban African Americans only worked to reinforce the political isolation of poor African Americans, which in turn served to strengthen political claims that their problems were not economic, but social. In as much as this was believed to be true, it followed that economic programs aimed at offering them opportunity could in no way correct the social pathologies plaguing inner city communities because these problems were considered to be behavioral, not economic (Weir 1992). Of course, these views were buttressed by a new social science that relied on the use of traditional methodologies, but for new ideological ends (Schram 1995). But the reliance on social science methodology also served to legitimate the position of those seeking to narrow the debate. The language of those seeking to localize the conflict became the politically acceptable discourse. The anti-poverty basis of the minimum wage, and by extension that type of rhetoric, was effectively discredited.

\section{CONCLUSION}

When one type of rhetoric is discredited it becomes incumbent upon the groups in opposition to reformulate their arguments. To a large extent, the rhetoric surrounding the minimum wage debate has come full circle. Its beginning locus was on a living wage intended to give workers dignity and preserve their individualism. From there it proceeded through macro policy, which assumed responsibility to reside with outside forces, and then through a backlash that again sought to place responsibility with the individual.

Despite these various permutations, a central theme running throughout and employed by both those seeking to narrow and socialize the debate, has been the meaning of individual independence. Those who seek to narrow the debate assert that an absence of wage policies allow individuals to be self-reliant and take responsibility for themselves. Those who seek to widen the debate assert that government policies that ensure that workers earn a living wage reduces or eliminates dependence on the state (for public assistance) or other private charities.

These may well represent competing visions for which rhetoric serves as a practical expression. 
At the same time, it doesn't mean that there may not be a new appreciation among those who have traditionally been skeptical of minimum wage increases for the role that the minimum wage can play for achieving a variety of economic goals, such as income distribution (cf. Freeman 1996).

New empirical literature showing minimum wage increases to have little effect on employment in an environment that has seen the value of the minimum wage fall and wage inequality rise has only worked to put the minimum wage back on the table (Card and Krueger 1995; Lang and Kahn 1998; Waltman, McBride, and Camhout 1998; Levin-Waldman and McCarthy 1998; Levin-Waldman 1999b). In addition to new findings that suggest that increases don't necessarily have the predicted textbook effect, there also appears to be a new understanding that the collapse of the minimum wage as well as declining power of unions and fewer welfare protections may have contributed to rising wage inequality (Fortin and Lemieux 1997, Galbraith 1998). Despite shifting rhetoric, certain realities have remained the same. Just as economic transformations in the past have left low-skilled workers in states of vulnerability, so too have more recent transformations, i.e. from industrialism to post-industrialism. Until recently, wages of low-skilled workers have not kept pace with inflation. Also until recently, the dependent poor had little incentive to forsake welfare for low-wage work-jobs most likely to pay minimum wages - because they wouldn't have been any better off from working (Bane and Ellwood 1994). But in the last couple of years, welfare policies that may in the past have had the effect of raising the reservation wages of the poor, have been changed so that recipients are left with little choice but to enter the labor market.

While living wage ordinances may have their political appeal, it would also appear that a new appreciation for the role that the minimum wage can play is leading some to reassess its use for accomplishing more than simply attaining a liveable wage. Richard Freeman in particular has observed that in the U.S. the minimum wage can both improve the well being of some lowwage workers while also slowing down the growing wage inequality. Moreover, it can serve to reorient the nature of the political and policy debate. As Freeman puts it: "If a minimum wage directs the attention toward the need to develop long-term policies that augment the productivity and skills of the low-paid, and of the firms for whom they work, it can provide an additional service as well as redistributing modest amounts to the low-paid (Freeman 1996, p. 648).” 


\section{REFERENCES}

Adkins v. Children's Hospital. 1922. 261 U.S.

Atlerson, James B. 1989-90. “The Prospects for Labor Law Reform.” Political Studies Journal. 18,2 (Winter): 364-373.

Baldwin, Stephen E. and Robert S. Goldfarb. 1996. "Minimum Wage Policy and Research: What's a Person to Believe?" in Garth Mangum and Stephen Mangum eds. Of Heart and Mind: Social Policy Essays in Honor of Sar A. Levitan. Kalamazoo, Mich.: W.E. Upjohn Institute for Employment Research.

Bane, Mary Jo, and David T. Ellwood, 1994. Welfare Realities: From Rhetoric to Reform. Cambridge, Mass: Harvard University Press.

Bowles, Samuel, David M. Gordon, and Thomas E. Weisskopf. 1983. Beyond the Wasteland: A Democratic Alternative to Economic Decline. New York: Doubleday.

Brown, Charles. 1988. "Minimum Wage Laws: Are they Overrated?" Journal of Economic Perspectives. 2, 3 (Summer): 133-145.

Brown, Charles, Curtis Gilroy and Andrew Kohen. 1982. "The Effect of the Minimum Wage on $487-528$.

Employment and Unemployment." Journal of Economic Literature 20 (June):

Burkhauser, Richard V. and T. Aldrich Finegan. 1989. "The Minimum Wage and the Poor: The End of a Relationship." Journal of Policy Analysis and Management. 8,1: 53-71.

Card, David and Alan B. Krueger. 1995. Myth and Measurement: The New Economics of the Minimum Wage. Princeton N.J.: Princeton University Press.

Dolbeare, Kenneth M. 1986. Democracy at Risk: The Politics of Economic Renewal. Chatham, N.J.: Chatham House Publishers.

Dubofsky, Melvyn. 1994. The State \& Labor in Modern America. Chapel Hill N.C.: The University of North Carolina Press.

Elkin, Stephen L. 1987. City and Regime in the American Republic. Chicago: University of Chicago Press.

Filene, Edward A. 1923. "The Minimum Wage and Efficiency." American Economic Review. 13 (September): 411-415.

First National Maintenance Corporation v. National Labor Relations Board 452 U.S. (1980)

Foner, Eric. 1998. The Story of American Freedom. New York: W.W. Norton \& Co. 
Fortin, Nicole M., and Thomas Lemieux. 1997. "Institutional Changes and Rising w age Inequality: Is There a Linkage?" Journal of Economic Perspectives 11,2 (Spring): 7596.

Fraser, Steve, and Gary Gerstle ed. 1989. The Rise and Fall of the New Deal Order, 1930-1980. Princeton: Princeton University Press.

Freeman, Richard B. 1996. “The Minimum Wage as a Redistributive Tool.” The Economic Journal. 106 (May): 639-649

Galbraith, James K. 1998. Created Unequal: The Crisis in American Pay. New York: Basic Books.

Glickman, Lawrence B. 1997. A Living Wage: American Workers and the Making of Consumer Society. Ithaca N.Y.: Cornell University Press.

Goldfield, Michael. 1987. The Decline of Organized Labor in the United States. Chicago: University of Chicago Press.

Hart, Vivien. 1994. Bound by Our Constitution: Women, Workers, and the Minimum Wage. Princeton, N,J,: Princeton University Press.

Hurt, Charles. 1998. "Detroit Voters Back 'Living Wage' Despite Costs to City, Taxpayers." The Detroit News (November).

Hutchinson, Emilie. J. 1919. "Women's Wages: A Study of the Wages of Industrial Women and Measures Suggested to Increase Them." Studies in History, Economics and Public Law. New York: Columbia University. 89,1: 1-179.

Katz, Michael B. 1989. The Undeserving Poor: From the War on Poverty to the War on Welfare. New York: Pantheon Books.

Kamolnick, Paul. 1993. "American Workers and the Future of Minimum Wage Politics." Review of Radical Political Economics. 25,2: 26-49.

Kaus, Mickey. 1992. The End of Equality. New York: New Republic/Basic Books.

Kessler-Harris, Alice. 1988. A Woman's Wage: Historical Meanings and Social Consequences. Lexington, Kent.: The University Press of Kentucky.

Kirkby, Diane. 1987. "The Wage-Earning Women and the State: The National Women's Trade Union League and Protective Labor Legislation, 1903-1923." Labor History. 28,1 (Winter): 54-74.

Kosters, Marvin H., ed. 1996. The Effects of the Minimum Wage. Washington: The AEI Press. 
Kosters, Marvin, and Finis Welch. 1972. "The Effects of Minimum Wages on the Distribution of Change in Aggregate Employment." American Economic Review. 62,3 (June):323332.

Lang, Kevin, and Shulamit Kahn. 1998. "The Effect of Minimum-Wage Laws on the Distribution of Employment: Theory and Evidence.” Journal of Public Economics. 69: 67-82.

Lehrer, Susan. 1987. Origins of Protective Labor Legislation for Women, 1905-1925. Albany N.Y.: State University of New York Press.

Levin-Waldman, Oren M., and George W. McCarthy. 1998. "Small Business and the Minimum Wage. Policy Note 3. The Jerome Levy Economics Institute.

Levin-Waldman, Oren M. 1999a. "The Minimum Wage and Regional Wage Structure." Working Paper No. 267.Annandale-on-Hudson, N.Y.: The Jerome Levy Economics Institute.

1999b. "The Minimum Wage Can be Raised: Lessons from the 1999 Survey of Small Business.” Policy Note 6. The Jerome Levy Economics Institute.

1998a. "Exploring the Politics of the Minimum Wage." Journal of Economic Issues. 32,3 (September):773-802.

1998b. "The Minimum Wage in Historical Perspective: Progressive Reformers and the Constitutional Jurisprudence of 'Liberty of Contract'." Working Paper No. 256. The Jerome Levy Economics Institute. forthcoming. "Minimum Wage and Justice?" Review of Social Economy.

Marx, Karl. 1967. Capital vol 1: A Critical Analysis of Capitalist Production, Frederick Engels ed. New York: International Publishers.

Mead, Lawrence M. 1986. Beyond Entitlement: The Social Obligations of Citizenship. New York: The Free Press.

Meyer Robert H., And David A. Wise. 1983. "The Effect of the Minimum Wage on the Employment Earnings of Youth." Journal of Labor Economics. 1,1: 66-100.

Mink, Gwendolyn. 1995. The Wages of Motherhood: Inequality in the Welfare State, 19171942.

Ithaca, N.Y. and London: Cornell University Press.

Moody, Kim. 1988. An Injury to All: The Decline of American Unionism. London \& New York: Verso. 
Mueller v. Oregon. 1907. 28 Supreme Court Reporter. (October).

Murray, Charles. 1984. Losing Ground: American Social Policy, 1950-1980. New York: Basic Books.

Neumark, David, and William Wascher. 1992. "Employment Effects of Minimum and Subminimum Wages: Panel Data on State Minimum Wage Laws." Industrial and Labor Relations Review 46,1 (October): 55-81.

Nordlund, Willis J. 1997. The Quest for a Living Wage: The History of the Federal Minimum Wage Program. Westport, Conn.: Greenwood Press.

Orwell, George. 1980. "Politics and the English Language." in Arthur M. Eastman et al., ed., The Norton Reader: An Anthropology of Expository Prose. New York: W.W. Norton \& Co.

Palley, Thomas I. 1998. Plenty of Nothing: The Downsizing of the American Dream and the Case for Structural Keynesianism. Princeton, N.J.: Princeton University Press.

Piore, Michael J. 1995. Beyond Individualism. Cambridge, Mass.: Harvard University Press.

Piore, Michael J, and Charles F. Sabel. 1984. The Second Industrial Divide: Possibilities for Prosperity. New York: Basic Books.

Piven, Frances Fox, and Richard A. Cloward. 1982. The New Class Wars: Reagan's Attack on the Welfare State and its Consequences. New York: Pantheon Books.

Polanyi, Karl. 1957. The Great Transformation: The Political and Economic Origins of Our Time. Boston: Beacon Press.

Pollin, Robert, and Stephanie Luce. 1998. The Living Wage: Building a Fair Economy. New York: The New Press.

Prasch, Robert E. 1998. "American Economists and Minimum Wage Legislation During the Progressive Era: 1912-1923." Journal of the History of Economic Thought. 22,2 (June): 161-175. 1996. "In Defense of the Minimum Wage." Journal of Economic Issues. 30,2 (June): 391-397.

Reich, Robert B. 1997. Locked in the Cabinet. New York: Alfred E. Knopf.

Schattschneider, E. E. 1975. The Semisovereign People: A Realist's View of Democracy in America. Hinsdale, Ill.: The Dryden Press.

Schram, Sanford F. 1995. Words of Welfare: The Poverty of Social Science and the Social 
Science of Poverty. Minneapolis: University of Minnesota Press.

Schulman, Bruce J. 1991. From Cotton Belt to Sunbelt: Federal Policy, Economic,

Development, and the Transformation of the South, 1938-1980. New York and Oxford: Oxford University Press.

Seltzer, Andrew J. 1995. "The Political Economy of the Fair Labor Standards Act of 1938." Journal of Political Economy. 103,6: 1302-1342.

Shuster, Beth. 1998. Council Moves to Force Living Wage Law on DWP." Los Angeles Times. Metro, Part B. (October 29): 3

Stigler George J. 1986. "The Goals of Economic Policy.” in Kurt R. Leube and Thomas Moore ed. The Essence of Stigler. Stanford, Calif.: Hoover Institution Press.

1946. “The Economics of Minimum Wage Legislation.” American Economic Review. (June): 358-365.

Tribe, Laurence H. 1988. American Constitutional Law. Second edition. Mineola, N.Y.: Foundation Press.

U.S. Congress. Hearings before the Committee on Labor and Human Resources. United States Senate. 1987. Minimum Wage Restoration Act of 1987. 100 Congress. $1^{\text {st }}$ session. S.837. Washington: Government Printing Office.

U.S. Congress. Hearings before the Committee on Labor and Human Resources. 1989. Minimum Wage Restoration Act of 1989. $101^{\text {st }}$ Congress, $1^{\text {st }}$ session. S.4. Washington: Government Printing Office.

Waltman, Jerold, Allan McBride, and Nicole Camhout. 1998. "Minimum Wage Increases and the Business Failure Rate." Journal of Economic Issues. (March): 229-233.

Webb, Sidney, and Beatrice. 1920. Industrial Democracy. London: Longsman, Green \& Co.

Weir, Margaret. 1992. Politics and Jobs: The Boundaries of Employment Policy in the united States. Princeton N.J.: Princeton University Press.

Wood, Gordon S. 1991. The Radicalism of the American Revolution. New York: Vintage Books.

1972. The Creation of the American Republic, 1776-1787. New York: W.W. Norton.

Wright, Gavin. 1986. Old South, New South: Revolutions in the Southern Economy Since the Civil War. New York: Basic Books. 